European journal of American studies

Special Issue: May 68

\title{
We Are All Undesirables: May 68 and its Legacy
}

Introduction

\section{Giles Scott-Smith}

\section{(2) OpenEdition Journals}

Electronic version

URL: https://journals.openedition.org/ejas/2802

DOI: $10.4000 /$ ejas.2802

ISSN: 1991-9336

Publisher

European Association for American Studies

Electronic reference

Giles Scott-Smith, "We Are All Undesirables: May 68 and its Legacy", European journal of American studies [Online], 3-2 | 2008, document 1, Online since 09 September 2008, connection on 08 July 2021. URL: http://journals.openedition.org/ejas/2802 ; DOI: https://doi.org/10.4000/ejas.2802

This text was automatically generated on 8 July 2021.

Creative Commons License 


\title{
We Are All Undesirables: May 68 and its Legacy
}

\author{
Introduction
}

Giles Scott-Smith

1 Once again, we pass through another anniversary year of 1968 , offering a further opportunity to reflect on why that year is seared onto the collective memory, why it continues to resonate within the popular political and cultural imagination. The images of the Latin Quarter in Paris, hazy through the tear gas, or pictures of Soviet tanks being hemmed in by Czech protestors, or the harrowing frames taken just after Robert Kennedy's assassination, are as iconic as any in the post World War II period. But getting beyond these in order to analyse the meaning of ' 68 and the Sixties as a whole can be difficult. We remain Bob Dylan's Mr. Jones, aware that something happened, but not entirely sure what it was. The initial impression is one of hope for change and rebellion against authority, but the outlines of what drove such rebellion and where it went after ' 68 are not always distinct. Violence was considered legitimate by some, as retribution for wars in South-East Asia or, for the more extreme, as the only possible response to an oppressive capitalist-authoritarian system, but violence, as Chicago, the Weathermen and the RAF, and the fates of Martin Luther King and Robert Kennedy showed, could dangerously get out of control. The carelessness of hope and rebellion had a dark side to be reckoned with, be it related to weapons or drugs, and it was not always clear from which direction it would come next. As the editorial in a recently established journal devoted entirely to the decade exclaimed, how can we account for the sixties as providing "in one instance, irreducible change and, in the next, overwhelming evidence of the dominance of the 'givenness of things"'?

2 There has been plenty written on the passage of events and the significance of ' 68 , a mini-industry in itself that perpetuates the myths and the monuments.ii Myths and monuments are exactly constructed to satisfy and sustain important messages for those who come afterwards - they serve a valuable social and political purpose, be it reactionary or revolutionary depending on the context. In doing so, however, they can overshadow other narratives, pushing alternative interpretations to the margins. Over 
the past decade or so, new paths for examining '68 and the Sixties have been opened up that look to delve into unexplored areas and bring out fresh perspectives. One important field in this respect has been the gradual assembling of a transnational history of sixties protest, not just in terms of a comparative analysis between countries but also with regard to the circulation of ideas and movements across borders. Revolutionary protests and wars in Vietnam, Latin America, and Africa pressured and threatened the global North (Moscow as much as Washington) with radical political change. The shifting sites of the counter-culture's 'magic center' (in the words of Rob Kroes) - San Francisco, London, New York, Paris, Prague, Berlin, Milan, Amsterdam, Montreal - were in important ways linked, but how those linkages came about (media, personal contact, common cause) and what their consequences were has provided a rich and worthy field for research.iii The recent collection of essays assembled by Martin Klimke and Joachim Scharloth, entitled 1968 in Europe, continues in this vein by providing next to the country studies a series of investigations into the transnational roots and movements of late sixties protest. . $^{\text {in }}$ Social causes crossed borders, and '68 epitomised "the questioning of the presumed omnipotence of the nation and the state" as the dominant markers of identity, allegiance, legitimacy, and control. ${ }^{v}$

3 Another area that has proven worthy of reflection has been to focus on the lines of development since the Sixties, not just in terms of rebellion but also in terms of how it triggered a response, predominantly in conservative politics, that ultimately came to fruition in the Western world during the 1980s and 1990s. After all, the legacy of the New Left continued to be fought out in the public realm of the early twenty-first century, ${ }^{\mathrm{vi}}$ and Nichola Sarkozy felt it necessary to demand that the French Left be defeated in the 2007 presidential election so that "the heritage of May ' 68 ...should be liquidated once and for all." vii In the United States these battles have been even more evident in defining political dividing lines. As one study on the American situation claims, "the New Left contributed mightily to the growth of conservatism," and the broader implications of civil rights and social policies in the U.S. "were shocks to the body politic that were certain to create a backlash." viii The backlash came in the form of neoconservatism, which was motivated by a strong sense that essential American values were being trampled on by both the domestic and foreign policy of Cold War Liberalism. ${ }^{\text {ix }}$ Vietnam led not only to protests against U.S. imperialism, but also to a regrouping of the Right based on the determination to get the job done properly, next time.

4 Above all, sixties protest heralded a rejection of the given and a search (if not a demand) for no restrictions in every aspect of social life. Ignoring the authority and requirements of family, work, study, recovering and revealing one's identity away from being "bent out of shape by society's pliers," a belief that things could be better if humans interacted differently, these were the driving forces that, for a while, seemed to know no limit. Added to this was the desire to leave the Cold War behind as an irrelevancy, a false, restrictive determinant of behaviour that satisfied only the old order and certainly did not fit the aspirations of the new. However, these trends, when carried through to their logical end-points, could easily result in playfulness, chaos, farce, or whatever interesting cocktail may emerge from the blending (if not the collision) of art and life. Rob Kroes's comment on Amsterdam students carrying liberation from the structures of power so far that they ended up grading their own papers will no doubt raise a smile among EJAS readers. And whereas some systems of 
domination (race and class) came under heavy criticism, others (gender) seemed to continue as before.

The aim with this Special Issue was to find out how ' 68 and the legacy of the sixties feature in the work of the American Studies community forty years after the event. The results show that the period continues to resound and ricochet across disciplines as scholars continue to track revealing new lines of enquiry and expose linkages previously overlooked. This is the first Special Issue compiled for EJAS, and I would like to thank all those who have contributed, reviewed, or shown an interest in this project. I look forward to adding to the initial essays posted here as other material comes in. Roosevelt Study Center, Middelburg, The Netherlands

\section{NOTES}

i. Jeremy Varon, Michael S. Foley, and John McMillan, 'Time is an ocean: the past and future of the Sixties,' The Sixties, A Journal of History, Politics and Culture, 1 (June 2008). The journal aims to cover three main domains: "the Sixties themselves, their impact, and their construction in memory." The journal's first issue is online: http://www.informaworld.com/smpp/ title $\sim$ content $=\mathrm{g} 793750847 \sim \mathrm{db}=\mathrm{all}$ ii. As a selection see Barbara and John Ehrenreich, Long March, Short Spring: The Student Uprising at Home and Abroad (New York: Monthly Review Press, 1969); Edward E. Sampson, Harold A. Korn, et.al., Student Activism and Protest: Alternatives for Social Change (San Francisco: Jossey-Bass Inc., Publishers, 1970); George Katsiaficas, The Imagination of the New Left: A Global Analysis of 1968 (Boston: South End Press, 1987); Ronald Fraser et al, 1968: A Student Generation in Revolt (New York: Pantheon Books, 1988); David Caute, The Year of the Barricades (New York: Harper \& Row, 1988); Robert V. Daniels, Year of the Heroic Guerrilla: World Revolution and Counterrevolution in 1968 (Cambridge: Harvard University Press, 1989); Tariq Ali and Susan Watkins, 1968: Marching In The Streets (New York: The Free Press, 1998); Carole Fink, Phillip Gasser, and Detleff Junker, 1968, The World Transformed (Washington DC: German Historical Institute and Cambridge University Press, 1998); Mark Kurlansky, 1968: The Year That Rocked the World (New York: Ballantine Books, 2004).

iii. See for instance Arthur Marwick, The Sixties: Cultural Revolution in Britain, France, Italy, and the United States, 1958-1974 (New York: Oxford University Press, 1998); Ingrid Gilcher-Holtey, Die 68er-Bewegung: Deutschland, Westeuropa, USA (Munich: Beck, 2001); Gerd-Rainer Horn, The Spirit of '68: Rebellion in Western Europe and North America, 1956-1976 (Oxford: Oxford University press, 2007). iv. Klimke and Scharloth (eds.), 1968 in Europe: A History of Protest and Activism, 1956-1977 (New York/London: Palgrave Macmillan, 2008). Martin Klimke is also the author of the forthcoming title The 'Other' Alliance: Global Protest and Student Unrest in West Germany and the U.S., 1962-1972 (Princeton: Princeton University 
Press). Online Teaching and Research Guide available at www.

1968ineurope.com

v. See Akira Iriye and Rana Mitter, 'Foreword,' in Klimke and Scharloth (eds.), p. vii.

vi. See Paul Berman, Power and the Idealists (New York: W.W. Norton, 2005), a study which was triggered in January 2001 when Stern magazine publishing photographs of Joschka Fischer attacking a policemen in the street in Frankfurt in April 1973, Fischer, in 2001 the German Foreign Minister, was able to withstand the controversy this caused.

vii. 'Sarkozy attacks “immoral” heritage of 1968,' Daily Telegraph (1 May 2007), available online at http://www.telegraph.co.uk/news/worldnews/1550140/Sarkozyattacks-'immoral'-heritage-of-1968.html

viii. William L. O'Neill, The New Left: A History (Wheeler, IL: Harlan Davidson, 2001, p. 76.

ix. See for instance Irwin Stelzer, Neoconservatism (London: Atlantic, 2004).

\section{AUTHOR}

\section{GILES SCOTT-SMITH}

Roosevelt Study Center, Middelburg, The Netherlands 